\title{
Service Area of a Teachers College Library
}

Miss Byrnes, librarian, State Teachers College, Mayville, N.D., gave this, the first of four papers on the service area of a teachers college library, at the meeting of the Libraries of Teacher-Training Institutions Section, June 24, 1942.

$\mathrm{T}$ HE COLlege campus does not define the boundaries of the service of a college library. A college program that looks toward the development of not only the young people who make up its enrolment but of the adults and the children with whom these young people have contact in their field of service, must recognize an abundance of opportunities in the out-inthe-field service for the college library.

The effort to utilize these opportunities has resulted at the State Teachers College, Mayville, N.D., in ( I ) the establishing of a rural adult circulating library and (2) the development of a library-educational program in connection with the rural schools within the college community.

The rural adult circulating library was the outgrowth of different factors. Contributing to its inception was the fact that this community was privileged to belong to one of the Federal forum demonstration units for 1938-39. The other was the coming to the college in 1938 of Cyril W. Grace, who has the conviction that the college belongs to the people and that its services should contribute to and promote their welfare. Probably the fact that there is developing a new ferment for knowledge due to the world situation also had its part in the establishment of this service.

Calls began to come from adults in the surrounding community, and to aid in giving service the college library presented the matter to teachers in the rural schools. They were glad to cooperate in acting as custodians for books and library materials which the college library placed with them for circulation. School after school became interested and small centers developed.

In some cases it came about that one school exchanged with another before the materials were returned to the library. Once the library service was started, the insistence from the patrons has in most cases continued its development throughout the changes of teachers that might take place.

You are perhaps thinking that the college must have a large book appropriation to handle this demand. The contrary is true. It has such a pitiably small appropriation that last winter when the librarian was in attendanec at the midwinter meeting of the A.L.A., the discussion as to appropriations placed it in the scale below even the minimum.

Yet we have found that there are on library shelves books which can be placed for this use, excellent books which perhaps have not had a great deal of circulation 
since they met for a time some particular need.

Fortunately, too, pamphlets are now coming from presses in great numbers and can be purchased for small amounts. We have carefully made up a series of those considered authoritative and reliable and we draw heavily on this pamphlet source. Free and inexpensive material, too, is watched for in lists of every sort.

Since we are emphasizing service we shall omit details of management, such as the meetings with the teachers early in the school year, meeting the rural adults at different gatherings to which we are invited, the regulations of distribution and circulation, and the kinds of library material called for, which, incidentally, is of all kinds.

\section{Relations of College and Community}

We would say that this service to rural adults is having results in bringing about a closer, a confident, and kindly relationship between the college and community and is helping to awaken the people to the possibilities within themselves and within their own communities, a point on which we might elaborate to some extent.

The development of a library-educational program in connection with the rural schools within the college community is, as in the case of the previously mentioned service, again responsible to the reaching-out policy of the college, to a library-minded supervisor of rural education (Ellen V. Johnson), and to the established institution of Book Week, all of which cooperated with the college library to institute such a program.

Before the dates set for Book Week, the college library sends an invitation to outlying rural schools to participate in a function at the college during the closing day of the week-one year this function was a book festival, another a book convention. Just what it may be this year we are not sure. Anyway that would be telling and would spoil the surprise.

The "Festival" year we invited everybody and could scarcely handle the crowd. The "Convention" year brought "delegates" and many other guests, but not so many as to seriously disturb the decorum of the occasion.

The rural supervisor took materials to the schools in plenty of time before the date set for Book Week. The rural teachers and the parents helped find other material, and finally a program culminated in each school to which the parents were invited.

By some method on which they themselves agreed, one of the program numbers or parts of numbers cut to take not more than six to eight minutes each, were selected to be given at the college, as were displays which were to be brought in for exhibit.

\section{Finale of Program}

The ensemble program in the college auditorium was the finale of the whole function and as such drew a huge crowd. Parents and others in the different rural communities made this a time for a general gathering.

Different members of the college faculty helped in carrying out the schedule of the day. There were stories, introduction of new books-some of which were loaned us by the state library commission-demonstrations by the pupils of various library techniques in their own schools, explanations by student helpers of how to use the college library, visits with guides to the primary department, the greenhouse, and

(Continued on page 75) 
assistance to teachers. There are outstanding curriculum laboratories in all parts of this country. And studies are being made of such service. Let us become conscious of these workshops and, as soon as we get them well-established in our teachers college libraries, let us widen their usefulness by extending their service to teachers about us.

Rural schools, alumni, teachers of our area-three important groups-all, we believe, merit our attention. But how far shall we go? That's the question we must answer.

\section{Service Area of a Teachers College Library}

(Continued from page 70)

finally through the tunnel to West Hall where "tea" was served by book characters.

An entire year is none too long in which to get ready for this annual event. $\mathrm{Li}$ braries must be built up and put into shape. That means there must be money raised to help buy books and lists, and books must be perused from which to make the selection for purchase. And, to be sure, once the purchase is made, the books must be properly cared for. The college librarian or her helpers have frequent calls to the various schools to counsel with the young librarians or to have secret conferences regarding program parts. These parts are, likewise, in process all through the year. Two schools have written book plays and designed and made their own settings and costumes. All the schools have school papers which will be a part of the display this coming fall. And as to the history of books and homemade examples from the earliest wax tablets and parchment (homeprocessed) to a beautifully bound book of the present day, it is probable that the college students viewing the exhibit know less than do these rural school pupils.

Other than these services outside the boundary of the college campus there are the usual college library services to alumni and services through the office of interlibrary loans. These are more or less taken for granted. It is the two services regarding which I have spoken that help to define, as we see it, the service area of a college library, which area finally extends to whatever peoples and places having a contact with the college. 